
\title{
AdindaMas
}

Volume 1 Nomor 1, Juli 2021

\section{Pendampingan Pendirian Koperasi Unit Desa Berbasis Syariah Di Desa Karangmukti Bungursari Purwakarta}

\author{
Jalaludin ${ }^{1}$, Siti Rohmat ${ }^{2}$, Nurmala Ina Lestari ${ }^{3}$ \\ 1,2Sekolah Tinggi Iilmu Ekonomi Syariah (STIES) Indonesia Purwakarta \\ 1jalaludinstiesip@gmail.com \\ ${ }^{2}$ sitirohmat@sties-purwakarta.ac.id \\ ${ }^{3}$ Mahsiswa Sekolah Tinggi Iilmu Ekonomi Syariah (STIES) Indonesia Purwakarta \\ 3nurmalainal@gmail.com
}

\begin{abstract}
ABSTRAK
Pengabdian masyarakat ini bertujuan sebagai sarana memberikan wawasan tentang koperasi syariah bagi masyarakat di Desa Karangmukti Kec. Bungursari Purwakarta. Sekaligus memberikan pendampingan dan pemberdayaan ekonomi melalui pendirian kembali KUD, tetapi berbasis syariah. Koperasi Unit Desa (KUD) yang merupakan lembaga keuangan mikro (LKM) yang mampu melayani kebutuhan masyarakat pelaku usaha mikro dan kecil. Lembaga ini memfasilitasi terbangunnya kondisi (sistem, metoda, teknik dan output) terwujudnya perimbangan kekayaan yang tidak hanya berada pada segolongan masyarakat. Secara simultan, KUD Berbasis Syariah juga menjadi wadah sinergi masyarakat dan manciptakan kearifan lokal. Kearifan local yang dimaksud adalah bagaimana menyiapkan infrastruktur pembangunan berbasis partisipasi masyarakat lokal, yang tidak memiliki ketergantungan permanen pada bantuan, baik dari pemerintah maupun yang lain. Pelaksanaan KUD Berbasis Syariah dilakukan dengan bersandar kepada aturan syariah dan aturan koperasi yang ada selama tidak bertentangan dengan hukum syariah. Kekuatan nilai-nilai spiritual dan sosial dari KUD Berbasis Syariah ini menjadi kelebihan koperasi berbasis syariah dengan koperasi unit desa konvensional. Dalam menjalankan program pengabdian ini akan dilakukan dengan melakukan pendekatan metode; persiapan, pembelajaran, dan pendirian kembali KUD Berbasis Syariah.
\end{abstract}


Kata Kunci - Pendampingan, Penyuluhan, Pembangkitan, Koperasi Unit Desa, KUD Berbasis Syariah.

\section{ABSTRACT}

This community service aims as a means of providing insight into sharia cooperatives for the community in Karangmukti Village, Kec. Bungursari Purwakarta. At the same time providing assistance and economic empowerment through the re-establishment of KUD, but based on sharia. The Village Unit Cooperative (KUD) is a microfinance institution (LKM) capable of serving the needs of the community of micro and small business actors. This institution facilitates the development of conditions (systems, methods, techniques and outputs) for the realization of a balance of wealth that does not only belong to a group of people. Simultaneously, the Sharia-Based KUD is also a forum for community synergy and creating local wisdom. Local wisdom in question is how to prepare development infrastructure based on local community participation, which does not have a permanent dependence on assistance, either from the government or others. The implementation of Sharia-Based KUD is carried out by relying on sharia rules and existing cooperative rules as long as they do not conflict with sharia law. The strength of the spiritual and social values of the Shariabased KUD is the advantage of sharia-based cooperatives over conventional village unit cooperatives. In carrying out this service program, it will be carried out by using a method approach; preparation, learning, and re-establishment of Sharia-Based KUD.

Keywords - Assistance, counseling, establishment, Village Unit Cooperatives, ShariaBased KUD.

\section{PENDAHULUAN}

Desa Karangmukti merupakan salah satu Desa di Kecamatan Bungursari Kabupaten Purwakarta terletak di sebelah utara berada pada ketinggian $73 \mathrm{~m}$ dari permukaan air laut, keadaan tanah dataran dengan curah hujan rata-rata $2300 \mathrm{~mm}$, dengan suhu udara antara $24-26^{\circ} \mathrm{C}$. Adapun orbitrase yaitu dari Ibu Kota Kecamatan sejauh 5 Km, dari Ibu Kota Kabupaten sejauh 17 Km, dari Ibu Kota Provinsi sejauh $63 \mathrm{Km}$, dan dari Ibu Kota Negara sejauh $150 \mathrm{Km}$.

Berawal dari batas paling barat Desa Karangmukti akan langsung menemui Kampung Sukajadi, RW 04. Akan tetapi, sebelum Gapura Batas Desa Karangmukti terdapat rumah H. Endin Jaenudin selaku Kepala Desa Karangmukti. Di dalam RW 04 itu sendiri terdapat salah satu mata pencaharian sebagian warga Karangmukti berupa peternakan ikan lele dalam hal pembibitan dan pendederan. Peternakan ikan lele tersebut berada di halaman-halaman rumah warga dengan memaanfaatkan lahan yang mereka punya. Selain peternakan lele tersebut, di RW 04 juga terdapat beberapa lahan pertanian milik warga yang sebagian besar ditanami padi dan jagung. 
Setelah melewati RW 04 maka akan memasuki Kampung Karangmukti, RW 01 yang ditandai dengan keberadaan Kantor Desa Karangmukti. Di dalam RW 01 juga terdapat satu-satunya Sekolah Dasar Negeri yaitu SDN 01 Karangmukti. Selain itu di SDN 01 terdapat puskesmas pembantu namun letaknya berada di belakang perpustakaan SD sehingga tidak terlihat dengan baik oleh warga yang minim informasi.

Memasuki Kampung Sukamulya, RW 02 akan ditujukan dengan keberadaan Kantor Pos. Di RW 02 banyak dijumpai penggilingan padi atau tempat menyimpan hasil panen dari sawah milik warga. RW 02 ini berbatasan langsung dengan RW 03 yaitu Kampung Sukatani. Sebagaimana nama kampung tersebut sebagian besar warga di sini memiliki mata pencaharian sebagai petani dan buruh tani. Selama berada di RW 03 akan banyak dijumpai pematang sawah yang merupakan salah satu faktor penyokong perekonomian Desa Karangmukti. Sawah yang banyak terdapat di RW ini ditanami dengan bermacam-macam jenis tanaman pangan berupa padi, jagung, dan singkong. Di samping itu, juga terdapat bermacam-macam jenis sayuran seperti kacang panjang. Tidak jauh dari pematang sawah yang sangat luas akan dijumpai batas wilayah paling timur Desa Karangmukti yang berbatasan langsung dengan Desa Cijunti, Kec. Campaka.

Wilayah Desa Karangmukti sebagian besar digunakan untuk lahan pertanian dengan luas sawah 150, $70 \mathrm{Ha}$ dan luas ladang $61 \mathrm{Ha}$. Hal ini menunjukan bahwa sebagian besar penduduk Desa Karangmukti bermata pencaharian sebagai petani. Desa Karangmukti memiliki kendala kepemilikan lahan sawah, lahan sawah yang berada di Desa Karangmukti sebagian besar bukan milik warga Desa Karangmukti tetapi milik warga Desa Cikopo. Warga Desa Karangmukti hanya menyewa lahan dan menggarapnya.

Desa Karangmukti tidak memiliki pasar, lembaga perkreditan, dan koperasi, namun Desa Karangmukti memiliki satu kelompok tani yang bernama "Cinta Tani 1" yang diketuai oleh Bapak Darta. Kelompok tani di Desa Karangmukti berfungsi sebagai wadah belajar mengajar bagi anggotanya guna mengingkatkan pengetahuan, keterampilan dan sikap dalam bertani.

Melihat fakta diatas masyarakat yang sebagian pemenuhan kebutuhan ekonominya serba terbatas atau kekurangan, banyak terlibat hubungan dengan "rentenir" yang mereka sebut dengan bank keliling. Masalah umum yang muncul pada kondisi masyarakat yang banyak bergantung dengan "bank keliling" adalah himpitan ekonomi yang semakin berat karena umumnya bunga yang diambil pada pinjaman mereka sangat tinggi ${ }^{1}$. Bermula dari keprihatinan atas kondisi masyarakat tersebut tim Pengabdian Kepada Masyarakat (PKM) berencana mendampingi mendirikan Koperasi Simpan Pinjam dan Pembiayaan Syariah yang dikelola oleh Desa. Disamping untuk mendorong ekonomi mereka juga untuk menghindarkan

1 Aji Shonhaji, "Kearifan Lokal Dalam Desa Berbudaya: Studi Tentang Pengelolaan Desa Di Desa Cilandak Kecamatan Cibatu Kabupaten Purwakarta" (Universitas Islam Negeri Sunan Ampel Surabaya, 2017).

ADINDAMAS (Jurnal Pengabdian Kepada Masyarakat), Volume 1, Nomor 1, Juli 2021 http://journal.sties-purwakarta.ac.id/index.php/adindamas/ ISSN: xxxx-xxxx (Media Online) xxxx-xxxx (Media Cetak) 
masyarakat dari praktek ribawi yang secara tegas dan jelas dilarang oleh agama Islam. Sebagaimana tercantum dalam QS. Al-Baqarah ayat $275^{2}$.

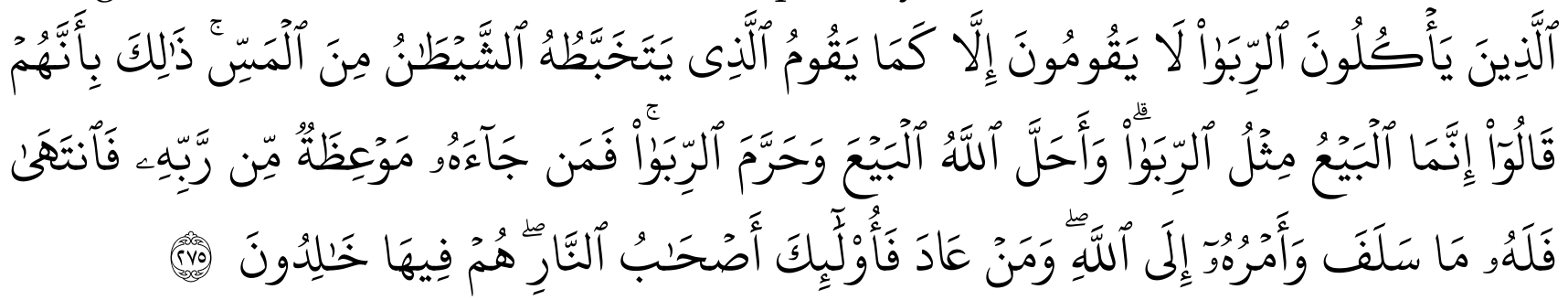

Orang-orang yang makan (mengambil) riba tidak dapat berdiri melainkan seperti berdirinya orang yang kemasukan syaitan lantaran (tekanan) penyakit gila. Keadaan mereka yang demikian itu, adalah disebabkan mereka berkata (berpendapat), sesungguhnya jual beli itu sama dengan riba, padahal Allah telah menghalalkan jual beli dan mengharamkan riba. Orang-orang yang telah sampai kepadanya larangan dari Tuhannya, lalu terus berhenti (dari mengambil riba), maka baginya apa yang telah diambilnya dahulu (sebelum datang larangan); dan urusannya (terserah) kepada Allah. Orang yang kembali (mengambil riba), maka orang itu adalah penghuni-penghuni neraka; mereka kekal di dalamnya. (QS. Al-Baqarah 275) ${ }^{3}$

Bahkan Imam al-Bukhari pun juga meriwayatkan sebuah hadits yang bersumber dari Abu Hurairah Ra bahwa Rasulullah SAW bersabda :

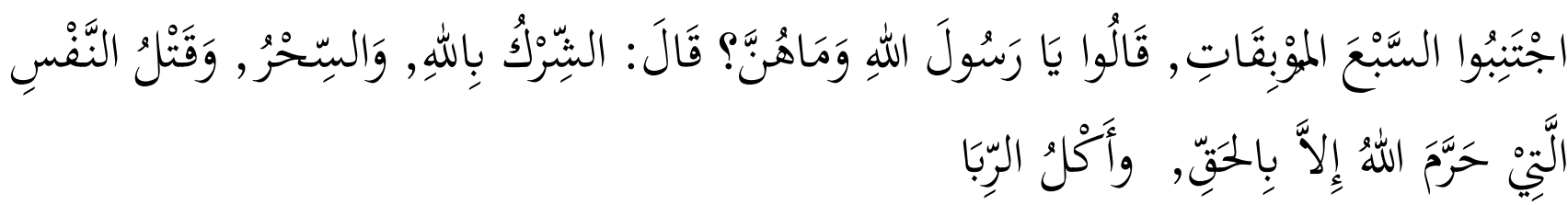

"Jauhilah tujuh perkara yang membinasakan." Para masyarakat bertanya, "Apa itu, wahai Rasulullah?" Beliau menjawab, "Syirik kepada Allah, sihir, membunuh jiwa yang diharamkan Allah kecuali dengan hak, memakan riba" (HR. Bukhari dan Muslim)

Selain itu, para wirausaha kecil dan menengah dalam mengembangkan usaha mereka terkendala dengan akses permodalan. Sulit bagi mereka untuk mengajukan dana mengajukan ke perbankan. Sehingga memaksa mereka harus berhubungan dengan bank keliling tersebut yang membebankan bunga sangat tinggi, pada akhirnya bukan memberikan kesejahteraan dan berkembang usahanya namun menambah beban dan membuat penurunan usahanya ${ }^{4}$.

2 Kiki Erika, Rina Nurhayati, and Moch. Cahyo Sucipto, "Kajian Ekonomi Syariah Dalam Pelaksanaan Asuransi Jaminan Kesehatan Pada Faskes Pertama Layanan BPJS Puskesmas Palasari Subang," EKSISBANK: Ekonomi Syariah dan Bisnis Perbankan 4, no. 2 (December 2, 2020): 201-213, accessed March 6, 2021, http://journal.sties-purwakarta.ac.id/index.php/EKSISBANK/.

3 Team Al-Fatih Berkah Cipta, Al-Quranul Karim: Tafsir Perkata Tajwid Kode Arab (Jakarta Timur: PT. Insan Media Pustaka, 2012), 47.

4 Winda Afriyenis, "Perspektif Ekonomi Islam Terhadap Utang Luar Negeri Pemerintah Dalam Pembangunan Ekonomi Indonesia," Maqdis: Jurnal Kajian Ekonomi Islam 1, no. 1 (2016).

ADINDAMAS (Jurnal Pengabdian Kepada Masyarakat), Volume 1, Nomor 1, Juli 2021 http://journal.sties-purwakarta.ac.id/index.php/adindamas/ ISSN: xxxx-xxxx (Media Online) xxxx-xxxx (Media Cetak) 
Tim PKM mendiskusikan terkait solusi yang dihadapi masyarakat, salah satunya membangkitkan koperasi yang sudah ada yaitu Koperasi Unit Desa (KUD), tetapi dari segi pengelolaannya dirubah dan disesuaikan dengan norma/ aturan/ prinsip syariah. Atau menggunakan pilihan yang kedua yaitu mendirikan koperasi simpan pinjam Syariah dari nol kembali. Namun, karena masih terkendala dengan SDM, biaya perizinan yang cukup besar jika mulai kembali dari nol, serta perlengkapan operasional koperasi, maka diputuskan untuk membangkitkan koperasi yang sudah ada (Koperasi Unit Desa), hanya dari segi pengelolaan disesuaikan dengan prinsip-prinsip syariah.

Berkaitan dengan hal di atas tim PKM menentukan tujuan dari pendampingan yaitu 1) Membangun infrastruktur lembaga keuangan dan keswadayaan yang efektif bagi kegiatan sosial-ekonomi dan produktifitas komunitas masayarakat produktif, kreatif, berpenghasilan dan masyarakat pada umumnya. 2) Mewujudkan amanah pembinaan dan pemberdayaan ekonomi masyarakat dan pendayagunaan dana masyarakat. 3) Mengintegrasikan potensi dan sumber daya ekonomi masyarakat dalam meningkatkan produktivitas ekonomi dengan basis partisipasi dan kepentingan bersama. 4) Menciptakan alternatif model penanganan program pemberdayaan masyarakat yang bertumpu pada etos kerja dan produktivitas masyarakat.

Salah satu diantara indikator penting pertumbuhan kegiatan ekonomi adalah adanya pertumbuhan transaksi keuangan sebagai akibat meningkatnya nilai ekonomi (added value of economy) dari kegiatan usaha tersebut ${ }^{5}$. Transaksi keuangan tersebut bisa bersifat perputaran dana (cash revolving) maupun penambahan dana karena terpenuhinya kebutuhan investasi dan atau penambahan nilai asset, dan hasil usaha dari kegiatan yang bersangkutan. Dalam konteks program pemberdayaan, lembaga keuangan yang dimaksudkan adalah Koperasi Unit Desa yang berbasis Syariah merupakan lembaga keuangan mikro (LKM) yang mampu melayani kebutuhan para pelaku usaha mikro dan kecil ${ }^{6}$. Disamping itu, lembaga ini juga memfasilitasi terbangunnya kondisi (sistem, metoda, teknik dan output) terwujudnya perimbangan kekayaan yang tidak hanya berada pada segolongan tertentu saja.

Secara simultan, KUD berbasis syariah juga menjadi wadah sinergi pelaku UKM dan menciptakan kearifan lokal. Kearifan lokal yang dimaksud adalah bagaimana menyiapkan infrastruktur pembangunan berbasis partisipasi warga local, yang tidak memiliki ketergantungan permanen pada bantuan, baik dari pemerintah maupun yang lain. Keberadaan KUD Berbasis Syariah akan mendorong peningkatan taraf

${ }^{5}$ Nurul Hasanah, Silvia Rosa, and Ach Bakhrul Muchtasib, "Pendampingan Pendirian Koperasi Simpan Pinjam Dan Pembiayaan Syariah Koperasi Dana Bakti Sahabat," Mitra Akademia 1, no. 2 (2018): 1-7.

${ }^{6}$ Lisa Dewi Anggraeni, Moch. Cahyo Sucipto, and Siti Rohmat, "Analisis Faktor Yang Mempengaruhi Masyarakat Muslim Menggunakan Jasa 'Bank Emok' Di Desa Cilalawi Kecamatan Sukatani Kabupaten Purwakarta," EKSISBANK (Ekonomi Syariah dan Bisnis Perbankan) 4, no. 2 (2018).

ADINDAMAS (Jurnal Pengabdian Kepada Masyarakat), Volume 1, Nomor 1, Juli 2021

http://journal.sties-purwakarta.ac.id/index.php/adindamas/

ISSN: $x x x x-x x x x$ (Media Online) $x x x x-x x x x$ (Media Cetak) 
ekonomi masyarakat sekitar secara bersama-sama ${ }^{7}$. Pemenuhan atas kebutuhan masyarakat relatif akan mudah terealisasi dengan berdirinya KUD berbasis Syariah, dimana KUD Berbasis Syariah ini memfasilitasi ketersediaan dana bagi masyarakat yang kekurangan/membutuhkan untuk kepentingan kehidupan mereka yang mana dana tersebut terhimpun dari masyarakat yang memiliki kelebihan dana, atau setidak-tidaknya dana tersebut sementara waktu tidak terpakai. Prosesi ini memperlihatkan masyarakat secara tidak langsung akan mengikatkan diri untuk saling mendukung pengembangan ekonomi mereka 8 .

Bermula dari realita bahwa kebutuhan masyarakat untuk pemenuhan hajat mendasarnya cukup tinggi sementara upaya untuk pengembangan taraf ekonomi relatif lemah karena keterbatasan dana/modal, begitupun akses permodalan ke lembaga keuangan sangat sulit bagi masyarakat kelas mikro dan kecil, sehingga mendorong beberapa tokoh masyarakat untuk memfasilitasi ketersediaan dana tersebut dengan cara melibatkan partisipasi masyarakat setempat dengan membangkitkan kembali lembaga keuangan berbentuk Koperasi Unit Desa yang berbasis syariah ${ }^{9}$. Dengan lembaga KUD Syariah ini akan masyarakat secara aktif akan terlibat dan turut andil dalam pengembangan ekonomi masyarakat sekitar. Seperti yang dilakukan oleh Pengurus KUD Syariah yang berada Desa Karangmukti Bungursari Purwakarta.

Diharapkan dengan KUD Berbasis Syariah dapat melakukan pembinaan dan pemberdayaan ekonomi masyarakat, sehingga mereka mampu berdaya taraf ekonominya ${ }^{10}$. Dengan bangkitnya KUD Berbasis Syariah ini, kelompok masyarakat diharapkan mendapatkan manfaat yang besar dalam melakukan pembinaan secara langsung dalam bidang ekonomi. Sebagaimana pengalaman beberapa masyarakat di Indonesia yang telah mendirikan KUD Berbasis Syariah untuk membina anggota/masyarakatnya ${ }^{11}$. KUD Berbasis Syariah yang dikelola dengan baik akan memberikan 'multiflier effect' bagi masyarakat sebagai stakeholders. Beberapa manfaat bagi stakeholders dapat digambarkan sebagai berikut: Bagi masyarakat umum yang membutuhkan dana, KUD Berbasis Syariah dapat menjadi alternatif pemenuhan kebutuhan atas lembaga keuangan. Lembaga keuangan seperti Bank dan sejenisnya, secara umum belum dapat menyentuh kebutuhan sebagian masyarakat banyak, terutama di kalangan pedesaan, usaha mikro dan kecil. KUD Berbasis

${ }^{7}$ Hasanah, Rosa, and Muchtasib, "Pendampingan Pendirian Koperasi Simpan Pinjam Dan Pembiayaan Syariah Koperasi Dana Bakti Sahabat."

8 Jalaludin Jalaludin and Heru Komarujaman, "Talent Management Dalam Meningkatkan Kinerja Lembaga KSPPS BMT Mitra Sadaya Cabang Purwakarta," EKSISBANK: Ekonomi Syariah dan Bisnis Perbankan 2, no. 1 (June 25, 2018), http:/ /journal.sties-purwakarta.ac.id/index.php/EKSISBANK/article/view/9.

${ }_{9}$ Ahmad Damiri, "Kontribusi Hukum Islam Dalan Proses Taqnin Undang-Undang Nomor 10 Tahun 1998 Tentang Perbankan," EKSISBANK (Ekonomi Syariah Dan Bisnis Perbankan) 2, no. 1 (2018).

${ }^{10}$ Hasanah, Rosa, and Muchtasib, "Pendampingan Pendirian Koperasi Simpan Pinjam Dan Pembiayaan Syariah Koperasi Dana Bakti Sahabat."

11 Ratna Patmawati, "Implementasi Akad Murabahah Pada Pembiayaan Rumah Non Bank Di Puri Nirana Cigelam Purwakarta," EKSISBANK (Ekonomi Syariah dan Bisnis Perbankan) 2, no. 2 (2018): 36-48.

ADINDAMAS (Jurnal Pengabdian Kepada Masyarakat), Volume 1, Nomor 1, Juli 2021 http://journal.sties-purwakarta.ac.id/index.php/adindamas/ ISSN: xxxx-xxxx (Media Online) xxxx-xxxx (Media Cetak) 
Syariah akan menjadi alternatif sumber memperoleh pembiayaan, maupun tempat menyisihkan sebagian pendapatan dalam bentuk tabungan maupun simpanan/ titipan. Selain manfaat ekonomi, KUD Berbasis Syariah dapat memberikan manfaat sosial bagi masyarakat, berupa peningkatan etos kerja, peningkatan rasa solidaritas dan kerjasama antar anggota masyarakat. Bagi masyarakat yang kelebihan dana KUD Berbasis Syariah dapat menjadi alternatif investasi12.

Dewasa ini sektor usaha mikro, kecil dan menengah sedang menjadi pilihan pembiayaan bagi perbankan. Hal ini disebabkan karena transaksi dengan usaha kecil ternyata dianggap sangat efektif dan menguntungkan serta memiliki risiko yang relatif kecil13. KUD Berbasis Syariah dapat memposisioningkan sebagai satu sektor investasi yang menguntungkan bagi investor maupun pemilik dana. Sementara bagi pengurus KUD Berbasis Syariah dapat menjadi pilihan yang tepat mewujudkan tanggung jawab sosial untuk ikut serta mendorong kemakmuran masyarakat di lingkungannya. Tidak seperti program charity, model seperti ini tidak berisiko terhadap munculnya sikap merasa ingin dimanja, atau sikap ketergantungan permanen terhadap bantuan. Semua masyarakat memiliki kesempatan dan peluang yang sama untuk memanfaatkan KUD Berbasis Syariah, tanpa harus diberi secara langsung. Berbeda dengan bantuan yang bersifat karitas, semakin banyak masyarakat yang harus dilayani, maka akan berakibat pada cost tinggi. Sedangkan dalam prinsip KUD Berbasis Syariah, semakin banyak terjadi transaksi masyarakat, maka akan semakin banyak peluang keuntungan yang akan diperoleh lembaga KUD Berbasis Syariah.

\section{METODE}

Dalam melaksanakan kegiatan ini akan menggunakan metode pelatihan dan pendampingan ${ }^{14}$, karena metode ini dianggap paling sesuai dan efektif dalam memberikan pemahaman secara langsung ke masyarakat. Dalam metode ini masyarakat akan didampingi secara langsung, namun sebelumnya akan dilakukan pelatihan sebagai pemahaman awal masyarakat secara teoritik ${ }^{15}$. Berdasarkan hal tersebut, maka diperkirakan secara mendasar akan dilakukan pendampingan dengan prioritas pembangkitan KUD Berbasis Syariah yakni:

12 Afriani Afriani, “Implementasi Akad Ju'alah Dalam Lembaga Keuangan Syariah," EKSISBANK (Ekonomi Syariah dan Bisnis Perbankan) 2, no. 2 (2018): 59-63.

${ }^{13}$ Hasanah, Rosa, and Muchtasib, "Pendampingan Pendirian Koperasi Simpan Pinjam Dan Pembiayaan Syariah Koperasi Dana Bakti Sahabat."

14 Ilfiandra Ilfiandra et al., "Pelatihan Dan Pendampingan Penulisan Karya Tulis Ilmiah Bagi Guru SD," Jurnal Pengabdian Pada Masyarakat 1, no. 1 (December 12, 2016): 70-81, http://ppm.ejournal.id/index.php/pengabdian/article/view/10.

${ }^{15}$ Nanis Hairunisya, "Pelatihan Dan Pendampingan Pembuatan Laporan Keuangan Kepada Pengusaha UMKM Di Kecamatan Karangrejo Kabupaten Tulungagung," J-ADIMAS: Jurnal Pengabdian Kepada Masyarakat 5, no. 2 (2017).

ADINDAMAS (Jurnal Pengabdian Kepada Masyarakat), Volume 1, Nomor 1, Juli 2021 http://journal.sties-purwakarta.ac.id/index.php/adindamas/ ISSN: xxxx-xxxx (Media Online) xxxx-xxxx (Media Cetak) 
a. Kebutuhan perangkat regulasi: legalitas perijinan, AD/ART, system dan prosedur, dan bentuk regulasi lain yang terkait.

b. Kebutuhan perangkat sosialisasi dan pelatihan

c. Kebutuhan mitra kerja dan SDM

Untuk mendukung pencapaian prioritas kebutuhan pembangkitan KUD Berbasis Syariah tersebut maka dilakukan tahapan pelaksanaan sebagai berikut:

a. Persiapan

Melakukan sosialisasi dan pengenalan lembaga KUD Berbasis Syariah kepada masyarakat. Dengan metode ini masyarakat diberikan gambaran secara umum tentang KUD Berbasis Syariah, manfaat dan keuntungannya bagi masyarakat. Metode ini dengan cara diskusi baik dilakukan dengan metode seminar ataupun workshop.

b. Pembelajaran

Memberikan pelatihan dasar tentang operasional KUD Berbasis Syariah, proses pendirian dan pengenalan produk KUD Berbasis Syariah. Pada tahapan ini kegiatan difokuskan pada para calon pengurus dan pelaksana KUD Berbasis Syariah dimana mereka yang akan terlibat secara langsung operasional KUD Berbasis Syariah tersebut.

c. Pembangkitan

Setelah tahapan pelatihan tersebut selesai diteruskan dengan program pendampingan terkait dengan revisi AD/ART, formulir KUD Berbasis Syariah, dan perlengkapan kerja lainnya yang menjadi syarat Perubahan KUD Berbasis Syariah secara legal dan terdaftar pada pemerintah.

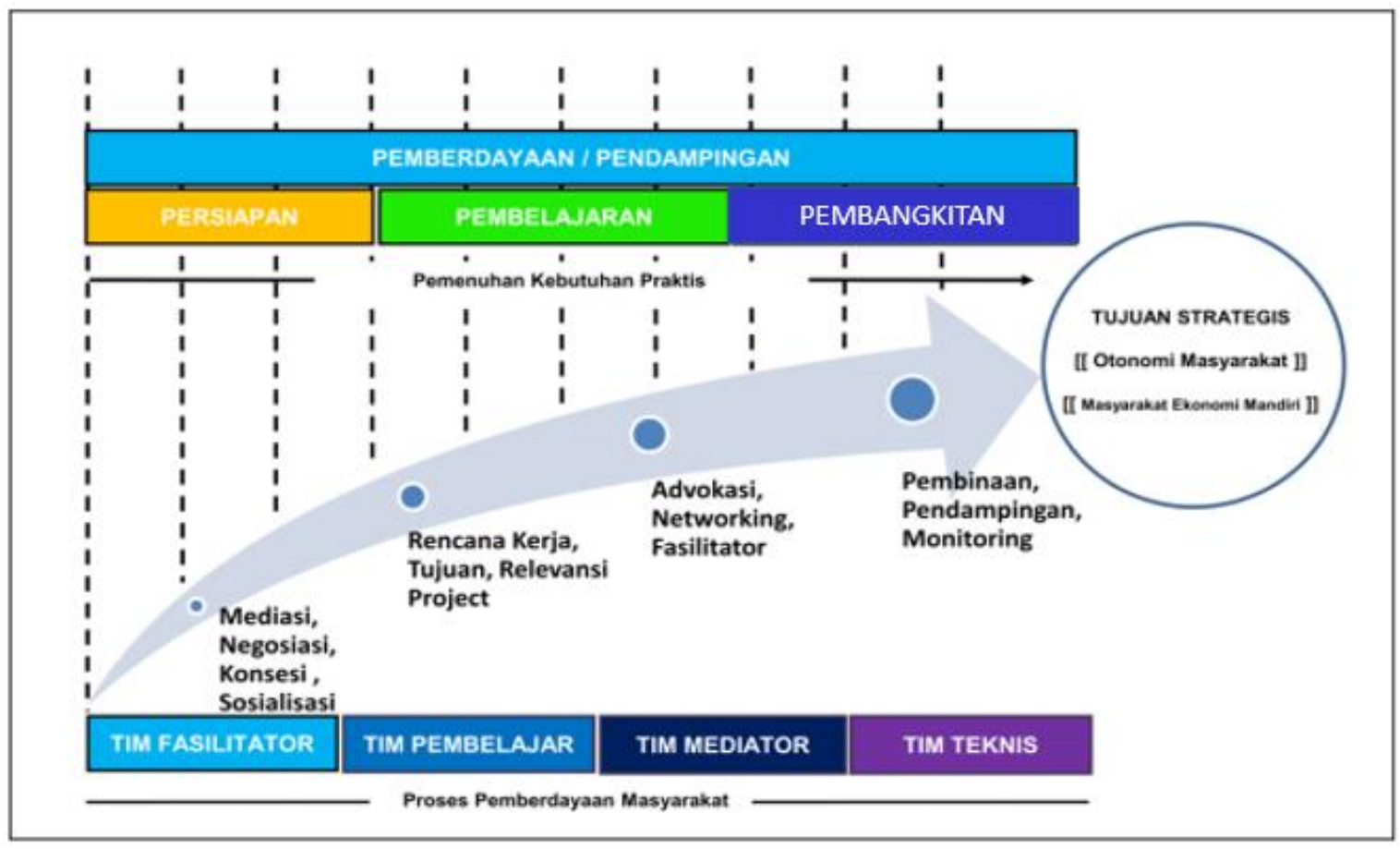

ADINDAMAS (Jurnal Pengabdian Kepada Masyarakat), Volume 1, Nomor 1, Juli 2021 http://journal.sties-purwakarta.ac.id/index.php/adindamas/ ISSN: $x x x x-x x x x$ (Media Online) $x x x x-x x x x$ (Media Cetak) 


\section{HASIL DAN PEMBAHASAN}

\section{A. Realisasi Kegiatan}

1. Persiapan Kegiatan Pengabdian

Dalam melaksanakan kegiatan Pengabdian Kepada Masyarakat untuk pendampingan pembangkitan KUD Berbasis Syariah Desa Karangmukti Kec. Bungursari Purwakarta, dilakukan beberapa tahapan persiapan, diantaranya:

a. Melakukan kordinasi dengan Kepala Desa Karangmukti untuk mendiskusikan tentang kesiapan pelaksanaan Sosialisasi dan Penyuluhan KUD Berbasis Syariah ke anggota.

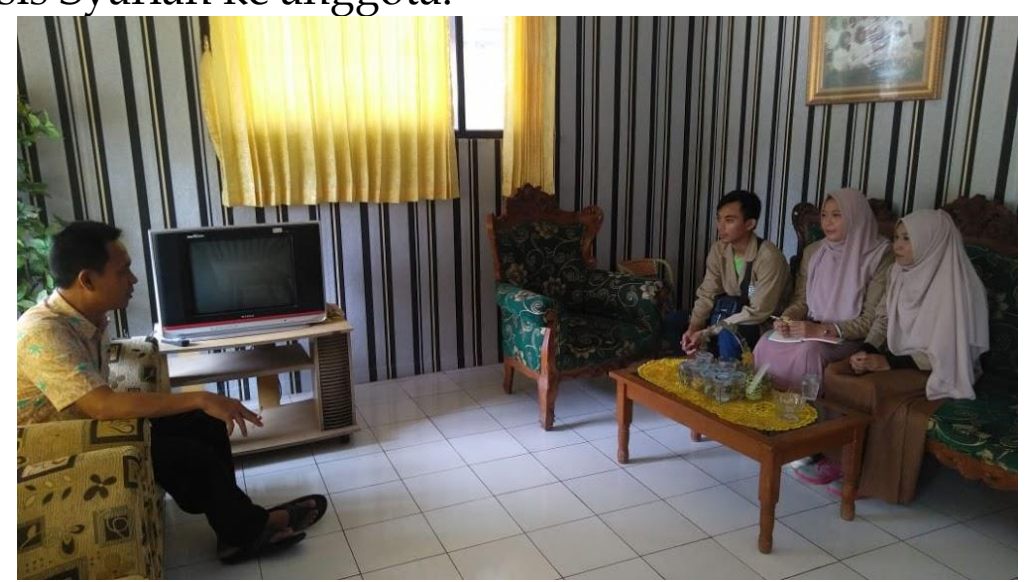

Gambar 3.1 Koordinasi tim PKM dengan kepala Desa

b. Rapat kordinasi Tim Pengbdian Kepada Masyarakat untuk menyusun jadwal kegiatan dan pembagian tugas.

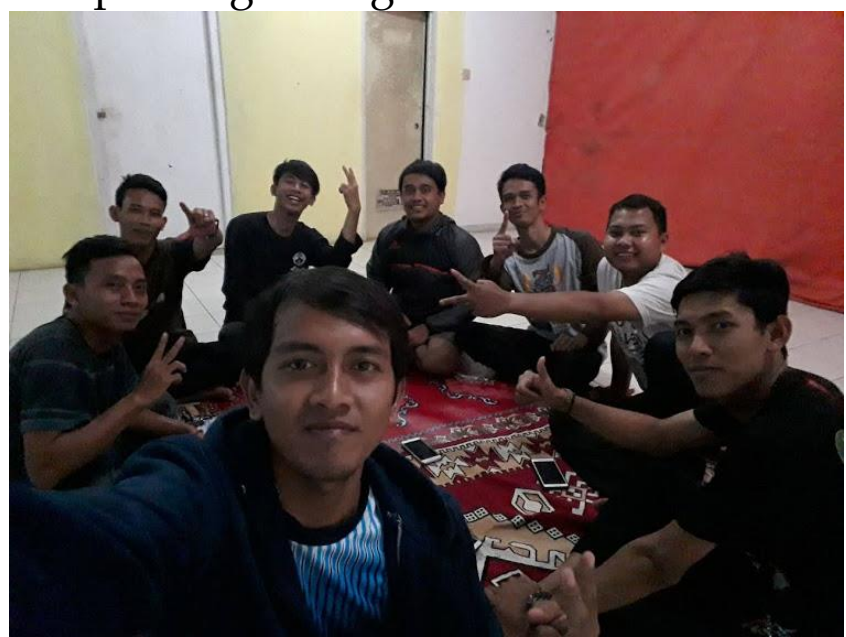

Gambar 3.2 Rapat kordinasi Tim PKM menyusun kegiatan

c. Menentukan dan menyusun materi pendampingan yang akan disampaikan dalam kegiatan pengabdian masyarakat. 


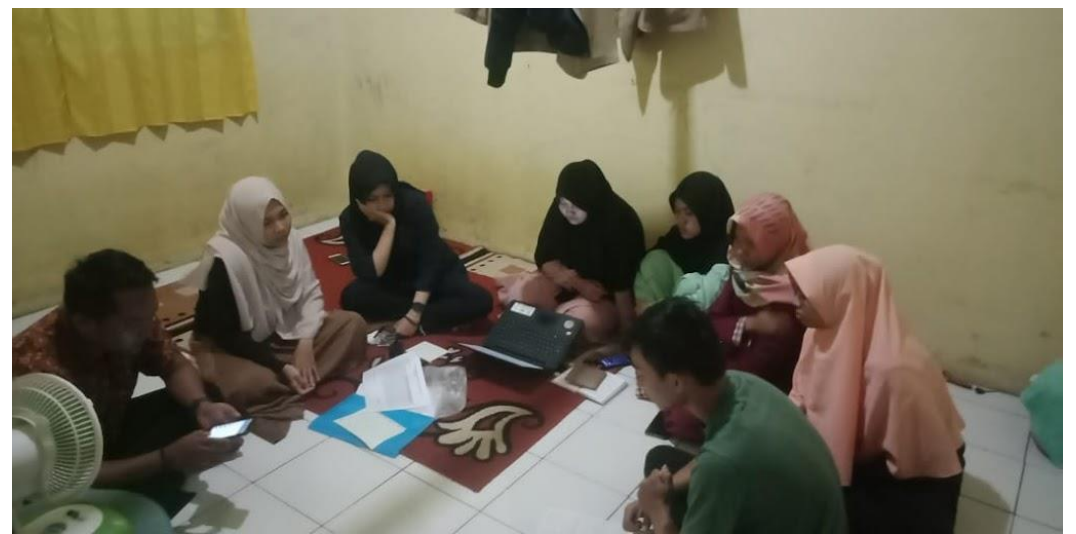

Gambar 3.3 Menentukan dan menyusun materi pendampingan

d. Menyusun kegiatan teknis pendampingan pembangkitan koperasi. Kegiatan Sosialisasi Pelaksanaan kegiatan sosialiasi untuk pendampingan pembangkitan KUD Berbasis Syariah Desa Karangmukti Kec. Bungursari Purwakarta hari Minggu, 16 Februari 2020. Hadir dalam kegiatan ini para mantan pengurus KUD, Karang Tatuna, dan Tokoh Masyarakat Desa Karangmukti Kec. Bungursari Purwakarta.

Dalam kegiatan sosialisasi ini disampaikan bahwa kegiatan pengabdian kepada masyarakat merupakan kegiatan yang lazim dilaksanakan oleh perguruan tinggi untuk melakukan pembinaan, pendampingan, dan pemberdayaan masyarakat sebagai bentuk tanggung jawabnya melakukan pengembangan di masyarakat. Disamping itu, dalam kegiatan sosialisasi ini dijelaskan secara teknis hal-hal yang akan dilakukan selama melakukan pendampingan pendirian. Diantaranya kegiatan penyuluhan, pendampingan penyusunan draft akta notaries, dan pendampingan revisi penyusunan anggaran dasar dan anggaran rumah tangga.

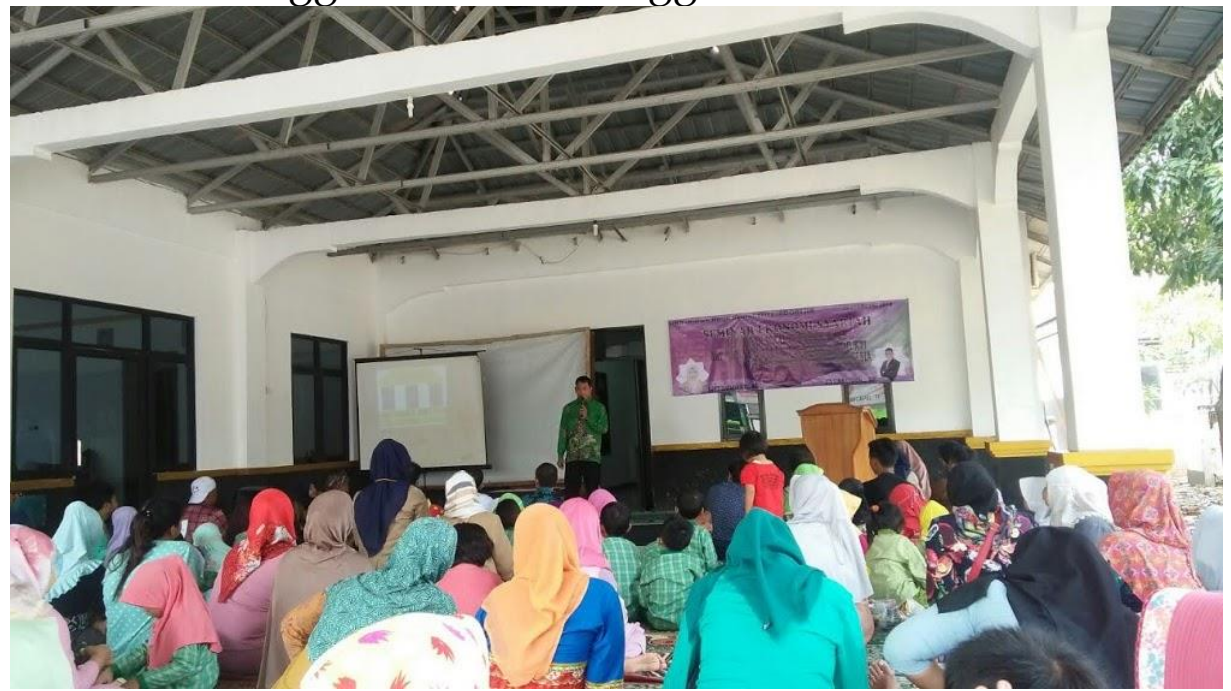

Gambar 3.4 Sosialisasi kegiatan Pengabdian

ADINDAMAS (Jurnal Pengabdian Kepada Masyarakat), Volume 1, Nomor 1, Juli 2021 http://journal.sties-purwakarta.ac.id/index.php/adindamas/ ISSN: $x x x x-x x x x$ (Media Online) $x x x x-x x x x$ (Media Cetak) 
2. Kegiatan Pendampingan

Kegiatan pendampingan dalam hal ini melakukan bimbingan teknis kepada para calon pengurus dan pelaksana harian untuk mempersiapkan kebutuhankebutuhan pembangkitan Desa Karangmukti Kec. Bungursari Purwakarta. Pendampingan yang telah dilaksanakan adalah menyusun draft akta notaries, yang berisi diantaranya berita acara rapat pembangkitan, absensi anggota beserta tanda tangannya, tanda pengenal anggota (KTP), bukti bayar simpanan pokok dan simpanan wajib, surat kuasa pengurusan pendirian koperasi, laporan cash flow, dan notulensi rapat pembangkitan. Selain pendampingan tersebut di atas, juga dilaksanakan pendampingan revisi penyusunan anggaran dasar dan anggaran rumah KUD Berbasis Syariah.

\section{B. Hasil Kegiatan}

1. Hasil Pelatihan

Berdasarkan hasil pengamatan, tanya jawab langsung dengan peserta, dan diskusi saat kegiatan penyuluhan KUD Berbasis Syariah telah memberikan hasil yang cukup baik untuk perkembangan pembangkitan KUD Berbasis Syariah, diantaranya:

a. Memberikan pengetahuan dan pemahaman peserta penyuluhan tentang koperasi dan KUD Berbasis Syariah. Perbedaan secara prinsip antara koperasi syariah dan koperasi konvensional, khususnya dalam pengurusan pendirian dan komponen yang dibutuhkan dalam pendirian.

b. Meningkatkan semangat dan motivasi peserta untuk segera mewujudkan akta notaries dan legalitas koperasi syariah pada lingkungan masyarakat di Desa Karangmukti Kec. Bungursari Purwakarta. Terutama segera terwujudnya harapan besar mereka, yaitu meminimalisir dan menghilangkan rentenir yang menjerat sebagian besar masyarakat di lingkungan Desa Karangmukti Kec. Bungursari Purwakarta.

2. Hasil Pendampingan

Dari kegiatan pendampingan secara teknis pelaksanaan pembangkitan KUD Berbasis Syariah ini telah dihasilkan:

a. Draft akta notaris KUD Berbasis Syariah

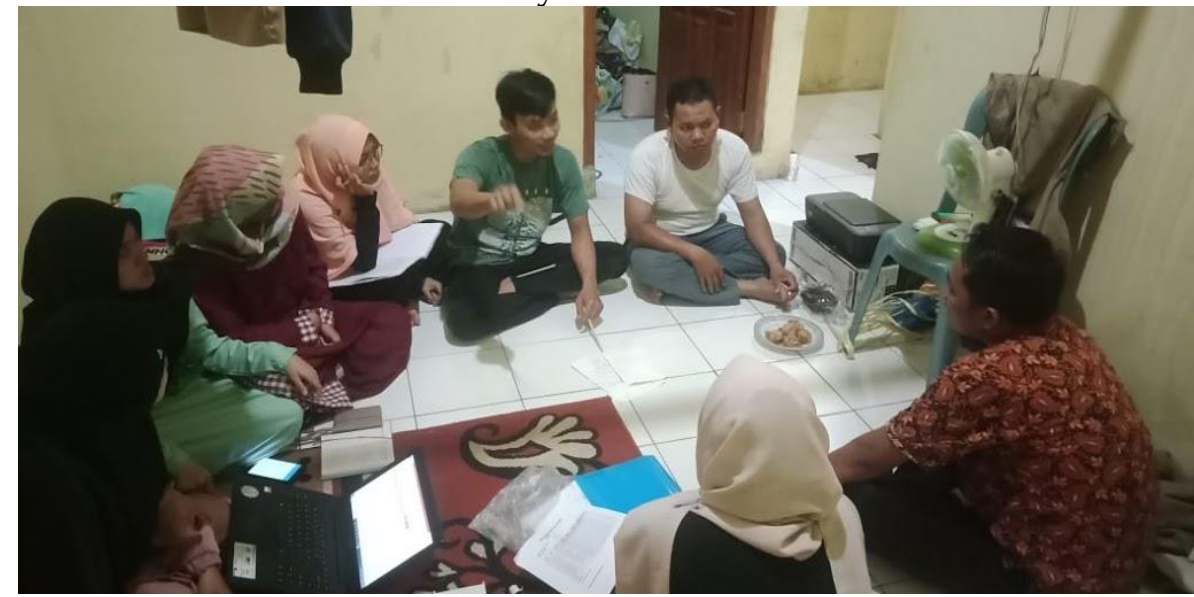

Gambar 3.5 Penyusunan Draft AD/ART

ADINDAMAS (Jurnal Pengabdian Kepada Masyarakat), Volume 1, Nomor 1, Juli 2021 http://journal.sties-purwakarta.ac.id/index.php/adindamas/ ISSN: xxxx-xxxx (Media Online) xxxx-xxxx (Media Cetak) 
b. Draft AD-ART KUD Berbasis Syariah

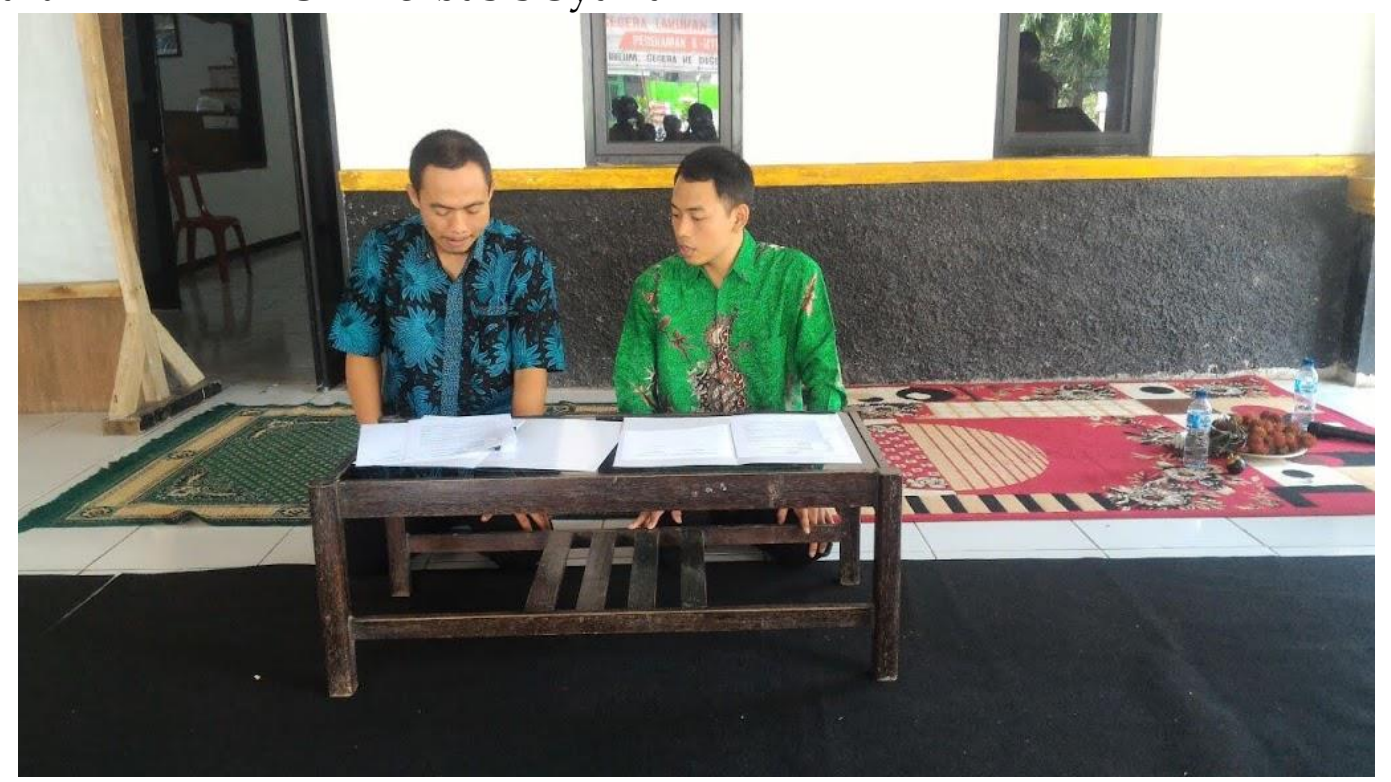

Gambar 3.6 Penyerahan Draft AD/ART

3. Hambatan Kegiatan

Kegiatan penyuluhan dan pendampingan KUD Berbasis Syariah telah berjalan dengan baik. Motivasi anggota terpicu untuk menyegerakan terbitnya legalitas dan realiasasi pelayanan simpan pinjam yang berbasis Syariah sebagai dasar operasional koperasi dan solusi terhindar dari jeratan rentenir. Meskipun demikian kegiatan pendapingan ini tidak berjalan sempurna. Terdapat beberapa hambatan yang mengganggu selama berjalannya pendampingan. Hambatan tersebut adalah faktor waktu. Kesibukan pengurus koperasi dan anggota koperasi sedikit menghambat jalannya pendampingan. Hambatan yang di maksud terjadinya beberapa kali penjadwalan ulang kegiatan sosialisasi, penyuluhan koperasi, dan penyusunan draft.

\section{KESIMPULAN}

Pelaksanaan pengabdian kepada masyarakat dalam bentuk pendampingan pendirian kembali KUD Berbasis Syariah ini sangat tepat. Dimana program ini sangat membantu terlaksananya KUD Berbasis Syariah. Kegiatan yang diawali dengan penyuluhan tentang koperasi kemudian dilanjutkan dengan pendampingan penyusunan draft legalitas koperasi, penyusunan anggaran dasar dan anggaran rumah tangga, serta pendampingan ke notaris memudahkan bagi para pengurus KUD Berbasis Syariah untuk mewujudkan terbentuknya koperasi yang mereka citacitakan. Pada awalnya mereka kebingungan dalam langkah-langkah pendirian kembali koperasi, dengan adanya pendampingan pendirian kembali KUD Berbasis Syariah dari Prodi Ekonomi Syariah dan Perbankan Syariah, rencana pendirian kembali KUD Berbasis Syariah dapat dilaksanakan lebih cepat. 


\section{UCAPAN TERIMAKASIH}

Pelaksanaan pengabdian kepada masyarakat banyak sekali pihak yang terlibat, baik dari teman-teman dosen, mahasiswa, dan pengurus koperasi KUD Berbasis Syariah. Ucapan terima kasih kami sampaikan kepada para pihak yang membantu terlaksananya pengabdian dengan lancar. Terima kasih kami sampaikan kepada LP2M STIE Syariah Indonesia Purwakarta, yang telah mensupport terlaksananya kegiatan PKM ini.

\section{DAFTAR PUSTAKA}

Afriani, Afriani. "Implementasi Akad Ju'alah Dalam Lembaga Keuangan Syariah." EKSISBANK (Ekonomi Syariah dan Bisnis Perbankan) 2, no. 2 (2018): 59-63.

Afriyenis, Winda. "Perspektif Ekonomi Islam Terhadap Utang Luar Negeri Pemerintah Dalam Pembangunan Ekonomi Indonesia." Maqdis: Jurnal Kajian Ekonomi Islam 1, no. 1 (2016).

Anggraeni, Lisa Dewi, Moch. Cahyo Sucipto, and Siti Rohmat. "Analisis Faktor Yang Mempengaruhi Masyarakat Muslim Menggunakan Jasa 'Bank Emok' Di Desa Cilalawi Kecamatan Sukatani Kabupaten Purwakarta." EKSISBANK (Ekonomi Syariah dan Bisnis Perbankan) 4, no. 2 (2018).

Damiri, Ahmad. "Kontribusi Hukum Islam Dalan Proses Taqnin Undang-Undang Nomor 10 Tahun 1998 Tentang Perbankan." EKSISBANK (Ekonomi Syariah Dan Bisnis Perbankan) 2, no. 1 (2018).

Hairunisya, Nanis. "Pelatihan Dan Pendampingan Pembuatan Laporan Keuangan Kepada Pengusaha UMKM Di Kecamatan Karangrejo Kabupaten Tulungagung." J-ADIMAS: Jurnal Pengabdian Kepada Masyarakat 5, no. 2 (2017).

Hasanah, Nurul, Silvia Rosa, and Ach Bakhrul Muchtasib. "Pendampingan Pendirian Koperasi Simpan Pinjam Dan Pembiayaan Syariah Koperasi Dana Bakti Sahabat." Mitra Akademia 1, no. 2 (2018): 1-7.

Ilfiandra, Ilfiandra, Uman Suherman, Sudaryat Nurdin Akhmad, Amin Budiamin, and Setiawati Setiawati. "Pelatihan Dan Pendampingan Penulisan Karya Tulis Ilmiah Bagi Guru SD." Jurnal Pengabdian Pada Masyarakat 1, no. 1 (December 12, 2016): 70-81. http://ppm.ejournal.id/index.php/pengabdian/article/view/10.

Jalaludin, Jalaludin, and Heru Komarujaman. "Talent Management Dalam Meningkatkan Kinerja Lembaga KSPPS BMT Mitra Sadaya Cabang Purwakarta." EKSISBANK: Ekonomi Syariah dan Bisnis Perbankan 2, no. 1 (June 25, 2018). http://journal.sties-purwakarta.ac.id/index.php/EKSISBANK/article/view/9.

Kiki Erika, Rina Nurhayati, and Moch. Cahyo Sucipto. "Kajian Ekonomi Syariah Dalam Pelaksanaan Asuransi Jaminan Kesehatan Pada Faskes Pertama Layanan BPJS Puskesmas Palasari Subang." EKSISBANK: Ekonomi Syariah dan Bisnis 
Perbankan 4, no. 2 (December 2, 2020): 201-213. Accessed March 6, 2021. http://journal.sties-purwakarta.ac.id/index.php/EKSISBANK/.

Patmawati, Ratna. "Implementasi Akad Murabahah Pada Pembiayaan Rumah Non Bank Di Puri Nirana Cigelam Purwakarta." EKSISBANK (Ekonomi Syariah dan Bisnis Perbankan) 2, no. 2 (2018): 36-48.

Shonhaji, Aji. "Kearifan Lokal Dalam Desa Berbudaya: Studi Tentang Pengelolaan

Desa Di Desa Cilandak Kecamatan Cibatu Kabupaten Purwakarta." Universitas Islam Negeri Sunan Ampel Surabaya, 2017.

Team Al-Fatih Berkah Cipta. Al-Quranul Karim: Tafsir Perkata Tajwid Kode Arab. Jakarta Timur: PT. Insan Media Pustaka, 2012. 